\title{
NORTHWEST PACIFIC MARINE RESERVOIR CORRECTION ESTIMATED FROM ANNUALLY BANDED CORAL FROM ISHIGAKI ISLAND, SOUTHERN JAPAN
}

\author{
Shinichiro Hideshima $\bullet$ Eiji Matsumoto $\bullet$ Osamu Abe $\bullet$ Hiroyuki Kitagawa ${ }^{1}$ \\ Institute for Hydrospheric-Atmospheric Sciences, Nagoya University, Furo-cho, Chikusa-ku, Nagoya, 464-8601, Japan
}

\begin{abstract}
We assessed marine reservoir age $R(t)$ for the costal area of the northwest Pacific using radiocarbon measurements of the annually banded coral core (Porites $\mathrm{sp}$ ) collected on Ishigaki Island in southern Japan. Reservoir age R(t) during the early 1900s at the Pacific coast of Ishigaki Island ranged between 290 and $455{ }^{14} \mathrm{C} \mathrm{yr}$, with a weighted mean of $355 \pm 25$ ${ }^{14} \mathrm{C} \mathrm{yr}(\mathrm{n}=5, \pm 1 \sigma)$. The regional-specific $\Delta \mathrm{R}$, defined as ${ }^{14} \mathrm{C}$ age difference of regional and world ocean surface layer, was 35 $\pm 25{ }^{14} \mathrm{C}$ yr $(\mathrm{n}=5, \pm 1 \sigma)$ on average and increased between 1900 and 1950 .
\end{abstract}

\section{INTRODUCTION}

The global-averaged ocean surface waters are depleted in radiocarbon content relative to the atmosphere by an amount equivalent to about $400{ }^{14} \mathrm{C}$ yr. Regionally, the oceans deviate from this value, reflecting variations of the ocean circulation and the ocean-atmosphere exchange rate (e.g. Stuiver and Braziunas 1993). Furthermore, the marine reservoir age need not be constant with time (Stuiver and Braziunas 1993; Bard et al. 1994). The knowledge of the regional deviation from the marine reservoir age and its stability with time is necessary to accurately calibrate ${ }^{14} \mathrm{C}$ ages of marine samples.

In general, marine reservoir ages in coastal waters have been indirectly determined from ${ }^{14} \mathrm{C}$ measurements of the pre-bomb shells that are not influenced by artificial ${ }^{14} \mathrm{C}$ input to the atmosphere by nuclear bomb tests. However, such fossil shells of known age are rare in the northwestern Pacific coastal areas (Yoneda et al. 2000). We investigated the annually banded coral, the age of which can be exactly determined.

In order to determine the marine reservoir age of the northwest Pacific and its temporal change, we performed ${ }^{14} \mathrm{C}$ measurements on the pre-bomb annually banded coral core sections collected from Ishigaki Island in southern Japan. Here we report $\mathrm{R}(\mathrm{t})$ and $\Delta \mathrm{R}$ values for the northwest Pacific coast over the period between 1900 and 1950 AD.

\section{SAMPLES AND METHODS}

The samples analyzed were collected from a 164-cm-long Porites species core (Lab code ISH993) drilled at a small channel of the fringing reef on the Pacific coast of Ishigaki Island $\left(24^{\circ} 33^{\prime} \mathrm{N}\right.$, $124^{\circ} 20^{\prime} \mathrm{E}$; Figure 1). The specimen of Porites species produces obvious annual growth bands. A majority of the growth sections are visible in X-radiographs. For the obscured sections of the annual-growth bands in X-radiographs, $\delta^{18} \mathrm{O}$ measurements were carried out at intervals of $2 \mathrm{~mm}$ for six sections of 5-77, 91-171, 441-539, 724-796, 798-902, and 970-1026 cm from the coral surface. The annual growth bands were confirmed by the seasonal $\delta^{18} \mathrm{O}$ variation of about $3 \%$ in amplitude.

The continuous sections consisting of pairs of three light and four dark annual growth bands were subsampled for conventional ${ }^{14} \mathrm{C}$ analyses. To avoid the potential contamination with secondary carbon, the coral surface was etched with $0.6 \mathrm{~N}$ hydrochloric acid (about $10 \%$ loss in weight) and then rinsed repeatedly with distilled water. The ${ }^{14} \mathrm{C}$ content of synthesized benzene was determined by a Wallac Quantulus 1220 liquid scintillation counter at the Institute for Hydrospheric-Atmospheric

${ }^{1}$ Corresponding author. Email: kitagawa@ihas.nagoya-u.ac.jp.

(C) 2001 by the Arizona Board of Regents on behalf of the University of Arizona Radiocarbon, Vol 43, Nr 2A, 2001, p 473-476

Proceedings of the 17 th International ${ }^{14} \mathrm{C}$ Conference, edited by I Carmi and $\mathrm{E}$ Boaretto 
Sciences, Nagoya University (Togashi and Matsumoto 1983). The correction for isotope fractionation was performed based on the $\delta^{13} \mathrm{C}$ values of a small portion of the synthesized benzene. The ${ }^{14} \mathrm{C}$ sample concentration $\left(\Delta^{14} \mathrm{C}\right)$ was calculated following the conventions of Stuiver and Polach (1977). The errors are at one sigma level. The typical uncertainty of $\Delta^{14} \mathrm{C}$ is about $5 \%$.

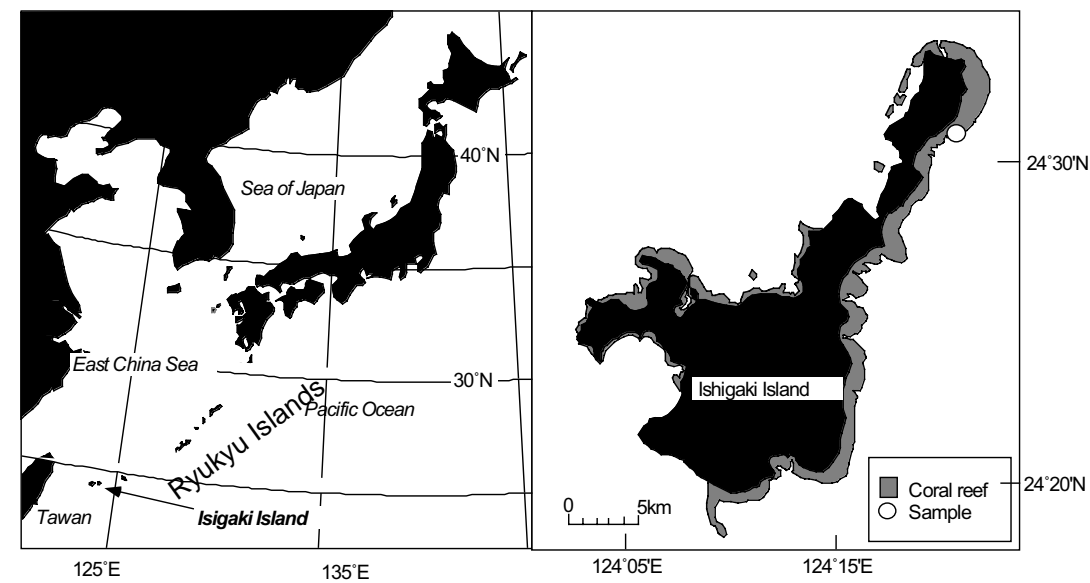

Figure 1 Locality map of Ishigaki Island, southern Japan. A 164-cm-long core (Lab Code IHS993) of Porites species was drilled at the channel of the fringing reef on the Pacific coast of the island $\left(24^{\circ} 33^{\prime} \mathrm{N}, 124^{\circ} 20^{\prime} \mathrm{E}\right)$.

\section{RESULTS ANS DISCUSSION}

Our results are summarized in Table 1 . We have calculated the reservoir age $\mathrm{R}(\mathrm{t})$ as the difference between the measured ${ }^{14} \mathrm{C}$ age of the coral and the atmospheric calibration data $\left({ }^{14} \mathrm{C}_{\mathrm{atm}}\right)$. The ${ }^{14} \mathrm{C}_{\mathrm{atm}}$ value for each analyzed period was determined based on a weighted mean of corresponding 4-year data from the single-year data set of tree rings (Stuiver et al. 1998). Based on the output of the mixed layer marine model calculation (Stuiver et al. 1998), we also calculated region-specific $\Delta R$, i.e. the sample age deviation from the marine calibration curve.

Table $1{ }^{14} \mathrm{C}$ ages of the annually banded coral (Porites $\mathrm{sp}$ ) from Ishigaki Island, southern Japan and their reservoir age $\mathrm{R}(\mathrm{t})$ and regional-specific $\Delta \mathrm{R}$

\begin{tabular}{lllllllr}
\hline Lab & $\begin{array}{l}\text { Depth } \\
(\mathrm{mm})\end{array}$ & $\begin{array}{l}\text { Analyzed } \\
\text { Period }\end{array}$ & $\begin{array}{l}{ }^{14} \mathrm{C} \text { age } \\
(\mathrm{yr} \mathrm{BP})\end{array}$ & $\begin{array}{l}\Delta^{14} \mathrm{C} \\
(\%)\end{array}$ & $\begin{array}{l}{ }^{14} \mathrm{C}_{\text {atm }} \text { age } \\
\left({ }^{14} \mathrm{C} \text { yr BP }\right)\end{array}$ & $\begin{array}{l}\mathrm{R}(\mathrm{t}) \\
\left({ }^{14} \mathrm{C} \text { yr }\right)\end{array}$ & \multicolumn{1}{l}{$\begin{array}{l}\Delta \mathrm{R} \\
\left({ }^{14} \mathrm{C} \text { yr }\right)\end{array}$} \\
\hline ISH993-1901 & $1526-1567$ & $1899-1902$ & $460 \pm 40$ & $-50 \pm 5$ & $65 \pm 10$ & $395 \pm 40$ & 5 \\
ISH993-1911 & $1390-1438$ & $1909-1912$ & $390 \pm 40$ & $-43 \pm 5$ & $100 \pm 10$ & $290 \pm 40$ & -60 \\
ISH993-1931 & $1091-1126$ & $1929-1932$ & $470 \pm 40$ & $-55 \pm 5$ & $160 \pm 10$ & $310 \pm 40$ & 10 \\
ISH993-1941 & $953-994$ & $1939-1942$ & $565 \pm 45$ & $-67 \pm 5$ & $180 \pm 15$ & $385 \pm 45$ & 100 \\
ISH993-1948 & $853-861$ & $1946-1949$ & $645 \pm 45$ & $-77 \pm 5$ & $190 \pm 15$ & $455 \pm 45$ & 175 \\
\hline
\end{tabular}

weighted average $R(t)=355 \pm 25$

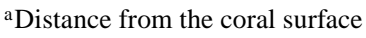

The marine reservoir age $R(t)$ at the Isigaki Island Pacific coast ranges between 290 and $455{ }^{14} \mathrm{C} \mathrm{yr}$. We calculated the weighted mean $\mathrm{R}(\mathrm{t})$ to be $355 \pm 25{ }^{14} \mathrm{C} \mathrm{yr}(\mathrm{n}=5, \pm 1 \sigma)$. The previous results for two shells collected at the Ryukyu Islands in 1934, show $R$ ( $t=1934$ ) of $210 \pm 50$ and $340 \pm 60 \mathrm{yr}$, 
with a weighted mean of $265 \pm 45{ }^{14} \mathrm{C}$ yr (Yoneda et al. 2000). The corresponding data of 1929-

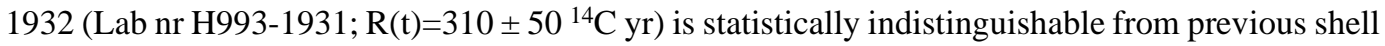
data of known historical age.

Marine reservoir ages may vary over time because they are affected not only by contemporary atmospheric ${ }^{14} \mathrm{C}$ levels but also by the integrated history of atmospheric ${ }^{14} \mathrm{C}$ levels. Therefore, $\Delta \mathrm{R}$ values, representing the offset between a local marine reservoir age and the average global ocean reservoir age (based on exchange models with atmospheric carbon reservoir; Stuiver and Braziunas 1986), are generally used to calibrate marine ${ }^{14} \mathrm{C}$ age. The coral samples from Ishigaki Island show small $\Delta \mathrm{R}$ values relative to the generally known $\Delta \mathrm{R}$ values for the north Pacific: about $100-200{ }^{14} \mathrm{C}$ yr (Stuiver and Braziunas 1993; Stuiver et al. 1986). The weighted mean of $\Delta \mathrm{R}$ values is $35 \pm 25{ }^{14} \mathrm{C}$ $\operatorname{yr}( \pm 1 \sigma)$, supporting to use the marine calibration curve with standard parameter $(\Delta \mathrm{R}=0)$ when general precision ${ }^{14} \mathrm{C}$ dating is carried out. The age of a marine reservoir that is in a steady-state carbon exchange equilibrium with the atmosphere reservoir increases with ocean-to-atmosphere reservoir size ratio. Therefore, the reservoir age of a small water body such as the channel of the fringing reef, if viewed as a separate reservoir with a restricted water exchange equilibrium with the world (open) ocean, is expected to be smaller than that of the Pacific surface water.

However, the scatter $\sigma$ (empirical standard deviation) of $\Delta \mathrm{R}$ is $90{ }^{14} \mathrm{C} \mathrm{yr}$, i.e. about 3 times the measuring uncertainty. This fact suggests that marine reservoir age at Ishigaki Island might not be constant over time. Our data shows a variation $\left(150-200{ }^{14} \mathrm{C}\right.$ yr) in $\Delta \mathrm{R}$ values between 1900 and 1950. Temporal variations of reservoir age and $\Delta \mathrm{R}$ value in the same interval have been reported in several oceanic areas such as the costal waters of Denmark (Heier-Nielsen et al. 1995) and California (compiled by Stuiver et al. 1986; Ingram and Southon 1997). These temporal $\Delta \mathrm{R}$ changes are considerably greater than the analytical error of the dated sample and must be considered for calibrating marine ${ }^{14} \mathrm{C}$ age.

The temporal changes of the old water upwelling along the Pacific west coast and/or the sea current of the North Pacific Gyre (Kuroshio warm current) along Ishigaki Island are possible explanations of the temporal $\Delta \mathrm{R}$ variation recognized in this study. The present and the future investigations of the temporal and spatial changes in marine reservoir age make it possible to understand marine environments such as ocean circulation and ocean-atmospheric exchange rate of the northwest Pacific.

\section{ACKNOWLEDGMENTS}

We thank T Ohuchi and M Sasaki for their field assistance. This research was financially supported by a special research project of the Institute for Hydrospheric-Atmospheric Sciences, Nagoya University (Dynamics of Atmospheric-Ocean Interaction).

\section{REFERENCES}

Bard E, Arnold M, Mangerud M, Paterne M, Labryrie L, Duprat J, Mélières MA, Sonstegaard E, Duplessy JC. 1994. The north Atlantic atmosphere-sea surface ${ }^{14} \mathrm{C}$ gradient during the Younger Dryas climatic event. Earth and Planetary Science Letters 126:275-87.

Heier-Nielsen S, Heinemeier J, Nielsen HL, Rud N. 1995. Recent reservoir age for Danish fjords and marine waters. Radiocarbon 37(3):875-82.

Ingram BL, Southon J. 1997. Reservoir ages in eastern Pacific costal and estuarine waters. Radiocarbon 38(3):573-82.
Stuiver M, Polach HA. 1977. Discussion: reporting ${ }^{14} \mathrm{C}$ data. Radiocarbon 19(3): 355-63.

Stuiver M, Pearson GW, Braziunas TF. 1986. Radiocarbon age calibration of marine samples back to 9000 cal yr BP. Radiocarbon 28(2B):980-1021.

Stuiver M, Braziunas TF. 1993. Modeling atmospheric ${ }^{14} \mathrm{C}$ influences and ${ }^{14} \mathrm{C}$ age of marine samples to 10,000 BC. Radiocarbon 35(1):137-91.

Stuiver M, Reimer PJ, Bard E, Beck JW, Burr GS, Hughen KA, Kromer B, McCormac G, van der Plicht J, Spurk M. 1998. INTCAL 98 radiocarbon age cali- 
bration 24,000-0 cal BP. Radiocarbon 40(3):104183.

Stuiver M, Reimer PJ, Braziunas TF. 1998. High-precision radiocarbon age calibration for terrestrial and marine samples. Radiocarbon 40(3):1127-51.

Togashi S, Matsumoto E. 1983. Radiocarbon dating method using benzene liquid scintillation. Bulletin of the Geological Survey of Japan 34:513-27. In Japa- nese with English abstract.

Yoneda M, Kitagawa $\mathrm{H}$, van der Plicht J, Uchida M, Tanaka A, Shibata Y, Morita M, Ohno T. 2000. Prebomb marine reservoir ages in the western Pacific: preliminary results on Kyoto University collection. Nuclear Instruments and Methods in Physics Research B172:377-81. 